\section{APLIKASI UKM SEBAGAI SOLUSI ALTERNATIF PENGELOLAAN KEUANGAN DAN UPAYA \\ MANAJEMEN \\ RISIKO PADA BUMDES KEMUDO MAKMUR}

\author{
Ambang Aries Yudanto ${ }^{1}$, Aditya \\ Wirawan ${ }^{2}$, dan Rani Gutomo ${ }^{3}$ \\ 1, 2, 3 Politeknik Keuangan Negara \\ STAN, Tangerang Selatan
}

Artikel

Diterima : 20 Desember 2019

Disetujui : 20 Desember 2019

Email :

ariesyudanto@pknstan.ac.id

\begin{abstract}
Abstrak
Kegiatan Pengabdian kepada Masyarakat ini memiliki tempat pelaksanaan pada Badan Usaha Milik Desa (BUMDesa) Kemudo Makmur, Desa Kemudo, Kabupaten Klaten. Tujuan kegiatan pengabdian masyarakat ini memberikan alternatif solusi bagi permasalahan penyusunan laporan keuangan BUMDesa, dan pemahaman terhadap potensi risiko BUMDesa yang dirasa masih perlu untuk ditingkatkan. Kegiatan yang dilakukan adalah dengan mengenalkan Aplikasi UKM sebagai solusi alternatif bagi permasalahan mengenai laporan keuangan, dan pengenalan proses penyusunan matriks risiko yang dapat memberikan informasi sederhana mengenai berbagai potensi risiko yang dihadapi oleh BUMDes. Kegiatan ini melalui berbagai tahapan diantaranya preliminary survey, wawancara terfokus serta pelatihan dan konsultasi.
\end{abstract}

Kata Kunci: Pengabdian Masyarakat, BUMDesa, Manajemen Risiko, Aplikasi UKM

\section{Abstract}

This Community Service Activity has been conducted in the VillageOwned Enterprises (BUMDesa) Kemudo Makmur, Kemudo Village, and Klaten Regency. The purposes of these community service activities are to provide alternative solutions to the BUMDesa's financial reporting problem and to enhance the awareness toward BUMDesa's potential risks. "Aplikasi UKM"is offered as an alternative solution to the financial statement problems. Introducing the risks matrix that may provide simple information about the potential raised by BUMDes become the following activity in these community service activities. The community service activities consist of preliminary survey, focused interview, training and consultation.

Keywords: Community Service, Village-Owned Enterprise, Risk Management, UKM application. 


\section{PENDAHULUAN}

Desa Kemudo merupakan salah satu desa yang berlokasi di Kecamatan Prambanan, Kabupaten Klaten, Provinsi Jawa Tengah. Tidak hanya menjadi desa yang paling luas, desa ini sekaligus juga menjadi desa yang dihuni paling banyak penduduk di wilayah Kecamatan Prambanan. Desa berpenghuni sebanyak 5448 jiwa ini berdekatan juga dengan salah satu primadona obyek wisata di sekitaran Jawa Tengah yaitu Kompleks Candi Prambanan (BPS Kabupaten Klaten, 2018).

Hal menarik lainnya adalah bahwa PT. Sarihusada Generasi Mahardika (PT. SGM), yang merupakan salah satu produsen segala macam susu maupun makanan, minuman kebutuhan bayi dan ibu hamil maupun menyusui, berlokasi di dalam wilayah Desa Kemudo. Hal ini memberikan dampak yang tentu saja dapat dirasakan oleh pemerintah desa maupun penduduk Desa Kemudo.

Di sisi yang lain, Pemerintah Desa Kemudo telah membentuk BUMDesa yang diberikan nama BUMDesa Kemudo Makmur. Inisiasi ini dalam rangka menjalankan amanat dari UU no 6 tahun 2014 tentang Desa, dimana Pemerintah Desa diberikan ruang untuk membentuk Badan Usaha Milik Desa (BUMDesa). BUMDesa ini merupakan merupakan Badan Usaha yang seluruh atau sebagian besar modalnya dimiliki oleh Desa melalui penyertaan secara langsung yang berasal dari kekayaan Desa yang dipisahkan guna mengelola aset, jasa pelayanan dan usaha lainnya untuk sebesar-besarnya kesejahteraan masyarakat Desa.

Salah satu tujuan BUMDes Kemudo Makmur didirikan adalah sebagai solusi atas pengelolaan limbah kering PT. Sarihusada Generasi Mahardhika (PT.SGM). Semula limbah kering PT.SGM dikelola secara perseorangan. Mekanisme pengelolaan seperti ini dinilai kurang memberikan kontribusi positif terhadap kehidupan masyarakat umum di sekitar pabrik PT.SGM. Setelah dilakukan pembahasan bersama antara pemerintah desa, PT.SGM, dan masyarakat, maka diputuskan bahwa BUMDes akan berperan sebagai perantara distribusi limbah kering dari PT.SGM. Dengan mekanisme baru tersebut, tidak hanya PT.SGM dan pembeli limbah kering yang mendapatkan keuntungan dari transaksi jual-beli ini, melainkan masyarakat Desa Kemudo juga mendapatkan manfaat dalam bentuk pembagian hasil usaha bersih.

BUMDes Kemudo Makmur yang secara resmi berdiri tahun 2016 dengan dasar hukum Perdes no 1 tahun 2016, kini mengelola dua unit usaha, yaitu: jual beli limbah kering sisa industri (dari PT. SGM) dan layanan umum. Dari kedua unit usaha tersebut, jual beli limbah kering sisa industri merupakan unit usaha utama BUMDes Kemudo Makmur. Limbah kering yang dikelola oleh BUMDes Kemudo Makmur secara umum terdiri dari 2 jenis: (1) afval industri (berupa bahan-bahan bekas kemasan) dan (2) kayu palet.

BUMDesa Kemudo Makmur telah mampu menyajikan neraca dan laporan laba rugi dan secara periodik telah menyampaikan laporan kegiatan operasi bisnis dalam forum musyawarah desa setiap tahunnya. Namun, dalam beberapa aspek detail, ada beberapa hal yang masih ada ruang untuk ditingkatkan dari sisi pengelolaan dan manajemen BUMDesa. Dalam sub-bab berikutnya akan dibahas secara lebih detail permasalahan-permasalahan yang ada di dalam pengelolaan BUMDesa 
Kemudo Makmur. Melalui tulisan ini, tim pengabdi akan lebih fokus untuk memberikan kontribusi dari sisi pengelolaan keuangan dan manajemen resiko dalam pengelolaan BUMDesa Kemudo Makmur.

\section{METODE}

Rangkaian pelaksanaan Pengabdian kepada Masyarakat ini dilaksanakan berbarengan dengan prosesi Kuliah Kerja Mahasiswa (KKM) dari Politeknik Keuangan Negara STAN (PKN STAN). Prosesi KKM diselenggarakan pada tanggal 22 s.d. 26 Juli 2019.

Metode yang digunakan dalam pengabdian masyarakat ini berupa preliminary survey, wawancara terfokus, serta pelatihan dan konsultasi. Dalam proses preliminary survey, tim pengabdian mencari tahu mengenai kondisi awal, baik dari sisi potensi maupun tantangan yang dihadapi oleh BUMDesa Kemudo Makmur. Preliminary survey dilaksanakan sebelum prosesi KKM berjalan. Kegiatan ini diawali dengan cara tim pengabdian berkunjung ke kantor BUMDes maupun Kantor Desa untuk bertemu dengan pihak-pihak terkait. Hal ini berguna untuk mendapatkan data awal mengenai permasalahan dari BUMDes yang akan menjadi obyek pengabdian.

Proses selanjutnya adalah wawancara terfokus kepada para pihak yang duduk sebagai pengelola BUMDes, diantaranya adalah Direktur, Bendahara dan beberapa pegawai lain di dalam BUMDes. Kegiatan ini dilakukan ketika rangkaian KKM mulai diselenggarakan, yaitu tanggal 22 s.d. 23 Juli 2019. Dari data awal yang diperoleh ketika preliminary survey, akan dilakukan proses konfirmasi ulang dan pendalaman terhadap permasalah yang ada. Tanggal 24 s.d. 26 Juli dilakukan proses pelatihan dan konsultasi secara privat terhadap pihak-pihak yang membutuhkan asistensi. Gambar 1 dapat menggambarkan proses-proses yang dilakukan. Yang mana pada praktiknya tidak terlalu mengikat, disesuaikan dengan kondisi dan situasi yang ditemui di lapangan, sehingga ada proses berulang yang kemungkinan terjadi seperti yang ada di dalam proses berupa wawancara terfokus dan proses pelatihan dan konsultasi.

Dalam proses pelatihan dan konsultasi, tim pengabdi juga memperkenalkan aplikasi Akuntansi UKM. Aplikasi yang bisa diunduh via gawai ini merupakan aplikasi sederhana dan aplikatif yang secara konsep ditujukan sebagai alat alternatif bagi para UKM untuk mengelola keuangannya. Namun, pada prakteknya, aplikasi ini dapat juga untuk membantu para pelaku BUMDes yang proses bisnis yang dilakukan relatif sama dengan UKM.

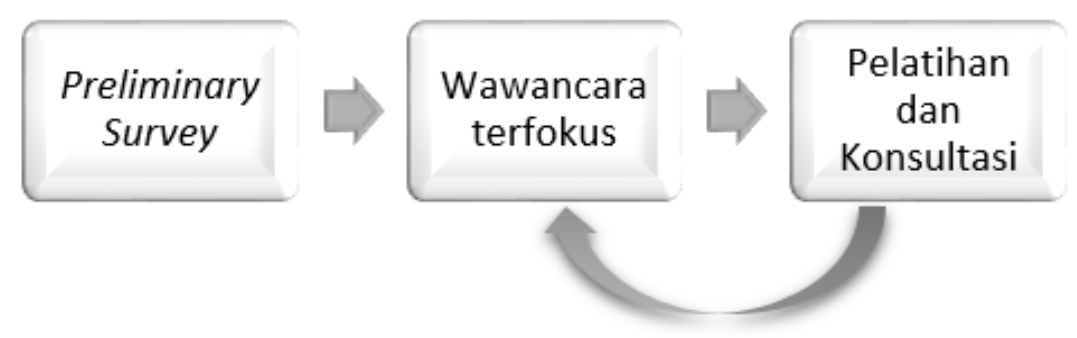

Gambar 1. Proses Kegiatan Pengabdian Masyarakat Sumber: diolah Penulis 
Secara garis besar, kegiatan ini memiliki target memberikan pemahaman kepada jajaran pengelola BUMDes Kemudo Makmur terkait pengelolaan keuangan dan pemetaan manajemen risiko yang akan dihadapi. Di sisi lain, tim pengabdi dari PKN STAN terdiri dari Tim Dosen sebanyak 2 (dua) orang dan 9 (sembilan) orang mahasiswa.

\section{HASIL \& PEMBAHASAN}

\section{Preliminary Survey}

Dalam kegiatan preliminary survey, tim pengabdi menurunkan tim kecil dari mahasiswa untuk mendapatkan gambaran awal mengenai kondisi yang dimiliki oleh obyek pengabdian. Kegiatan ini dilakukan beberapa hari sebelum rangkaian Kuliah Kerja Mahasiswa berjalan. Tim survey menggali data awal dari pihak-pihak terkait di lingkaran Desa Kemudo, baik itu pemerintah desa maupun dari personel BUMDes.

Dari proses preliminary survey ini, tim mendapatkan beberapa data awal, diantaranya adalah BUMDes Kemudo Makmur bergerak di dua bidang bisnis, yaitu pengelolaan limbah kering dari PT. SGM dan layanan umum masyarakat.

Dalam kapasitasnya dalam lini bisnis pengelolaan limbah kering ini, BUMDes Kemudo Makmur berperan sebagai penyalur limbah kering yang berupa kemasan bahan-bahan pembuatan susu (kertas, karton, kardus, dll) dari PT. SGM untuk kemudian dapat diolah lebih lanjut oleh masyarakat Desa Kemudo. Olahan masyarakat ini menghasilkan berbagai macam kerajinan, furniture dan perkakas yang berasal dari limbah kering, terutama limbah berupa palet kayu.

Dalam lini usaha berupa layanan umum, BUMDes Kemudo Makmur membuka layanan pembayaran PBB, BPJS, fotocopy, penjualan ATK yang menyasar masyarakat yang tinggal di Desa Kemudo.

Secara umum, melalui preliminary survey ini juga diperoleh berbagai permasalahan dan kendala yang ditemui oleh BUMDes Kemudo Makmur. Kendala yang dihadapi oleh BUMDes Kemudo Makmur ini cukup beragam, mulai dari permodalan, operasional proses bisnis harian BUMDes, sisi Sumber Daya Manusia pengelola dan beberapa hal lain. Namun dalam tulisan ini, penulis akan membatasi dan berfokus kepada dua kendala diantara beberapa kendala yang ada. Kendala-kendala yang akan menjadi fokus pembahasan di dalam artikel ini adalah yang berkaitan dengan penyusunan laporan keuangan BUMDes serta pemahaman terhadap potensi risiko BUMDes yang dirasa masih perlu untuk ditingkatkan.

\section{Wawancara terfokus}

Dari hasil preliminary survey yang telah dilakukan sebelumnya, maka kemudian dilanjutkan dengan wawancara terfokus. Tim Pengabdi mewawancarai Direktur, Bendahara dan bagian Operasional BUMDes Kemudo Makmur.

Melalui wawancara terfokus ini didapati bahwa BUMDes Kemudo Makmur memiliki sistem penyusunan laporan keuangan yang belum terintegrasi. Hal ini dapat berpotensi menimbulkan 
kesalahan pencatatan oleh operator yang berujung pada ketidaktepatan dalam penyajian laporan keuangan. Terlebih didapati bahwa keseluruhan personel yang ada di dalam BUMDes, baik yang bertanggung jawab di bagian keuangan maupun yang tidak, didorong untuk memiliki kemampuan dalam penyajian laporan keuangan.

Selain itu, dari perspektif yang lain, disampaikan bahwa BUMDes Kemudo Makmur seringkali menghadapi fluktuasi ketersediaan bahan baku berupa limbah kering maupun fluktuasi penjualan limbah kering ke rantai distribusi selanjutnya. Dari fenomena tersebut, tim pengabdi mengusulkan untuk dilakukan pemetaan potensi risiko yang akan dihadapi BUMDes Kemudo Makmur.

Dari kedua permasalahan di atas, tim pengabdi menindaklanjuti dengan (1) memperkenalkan aplikasi "Akuntansi UKM" sebagai salah satu alternatif sistem aplikasi terintegrasi yang dapat diterapkan di lingkungan BUMDes Kemudo Makmur, (2) melakukan penyusunan matriks risiko yang dapat memberikan informasi sederhana mengenai berbagai potensi risiko yang dihadapi oleh BUMDes Kemudo Makmur.

\section{Pelatihan dan Konsultasi}

Selanjutnya adalah proses pelatihan dan konsultasi. Di dalam kegiatan ini, tim pengabdi memberikan pelatihan singkat mengenai Aplikasi "Akuntansi UKM" dan cara melakukan pemetaan risiko sederhana.

Aplikasi “Akuntansi UKM" ini dipilih sebagai alternatif solusi bagi permasalahan mengenai laporan keuangan yang ada di BUMDes Kemudo Makmur dengan berbagai pertimbangan, diantaranya adalah (1) sifat aplikasi ini yang mudah dioperasikan, bahkan bagi personel yang memiliki pemahaman mengenai akuntansi yang masih minim, (2) aplikasi ini berbasis android dan dapat didapatkan secara mudah, dengan cara didownload melalui Google Playstore, (3) dapat menghasilkan berbagai jenis laporan keuangan sederhana secara terintegrasi dan otomatis,yang dapat diakses melalui telepon genggam maupun komputer (setelah dilakukan ekspor ke file excel). Dari berbagai keunggulan itulah, diharapkan aplikasi ini mampu memberikan kontribusi positif yang berkaitan dengan upaya penyusunan laporan keuangan BUMDesa secara lebih akurat dan presisi. Diantaranya mampu membantu menyusun laporan keuangan yang terintegrasi dan dapat meminimalisir adanya kesalahan pencatatan dari operator. Sifat sederhana dan user-friendly dari aplikasi ini juga diharapkan mampu untuk dioperasikan oleh personel yang memiliki pemahaman akuntansi yang masih minim.

Dari berbagai pertimbangan di atas, maka kemudian tim pengabdi mengenalkan aplikasi ini kepada personel BUMDes Kemudo Makmur. Materi yang diberikan kepada personel BUMDes adalah pengenalan fitur aplikasi "Akuntansi UKM", mulai dari mengunduh dari playstore hingga melakukan praktek simulasi sederhana. Keseluruhan prosesnya, tim pengabdi mendampingi dan mengarahkan simulasi, sehingga diharapkan personel BUMDes dapat mendapatkan gambaran hasil laporan keuangan yang dibutuhkan. 


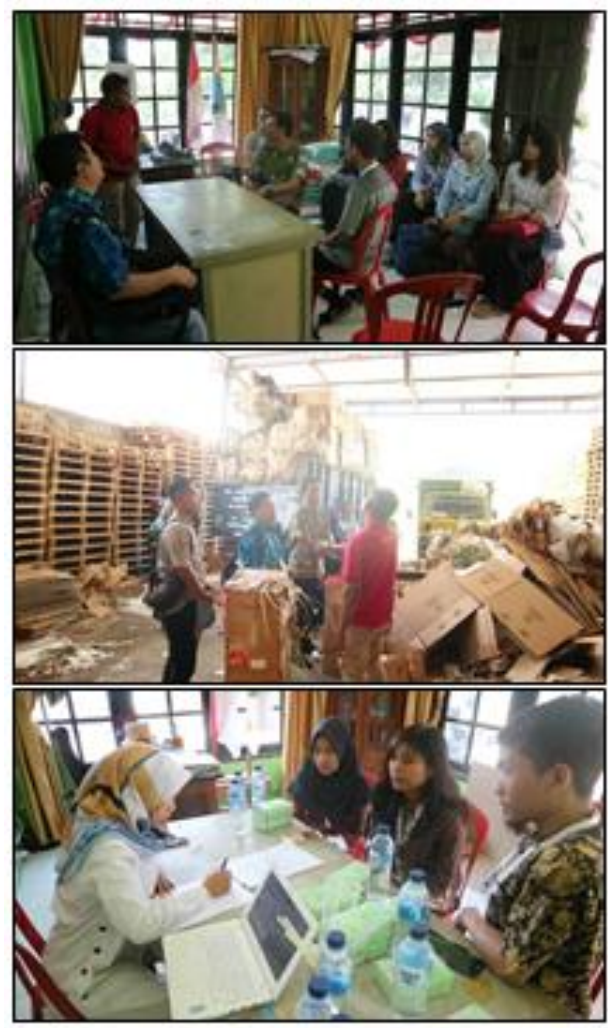

Gambar 2. Kegiatan-kegiatan yang dilaksanakan ketika Pengabdian Sumber: Dokumentasi Tim Pengabdi

Selanjutnya, dalam kegiatan penyusunan matriks risiko, tim pengabdi mencoba memberikan gambaran mengenai pentingnya manajemen risiko bagi sebuah organisasi. Manajemen risiko adalah pendekatan/metodologi terstruktur untuk mengelola ketidakpastian terkait ancaman. Kegiatan dalam manajemen risiko diantaranya adalah penilaian risiko, mengembangkan strategi untuk mengelolanya dan mitigasi risiko menggunakan pemberdayaan/manajemen sumber daya (Susanto \& Meiryani, 2018). Dalam prakteknya, perlu penulis batasi bahwa penyusunan matriks sederhana ini dilakukan lebih ke dalam rangka peningkatan kesadaran BUMDes Kemudo Makmur akan pentingnya pemahaman risiko yang ada dan bagaimana cara menghadapinya. Sehingga belum dapat dikatakan matriks risiko yang sempurna.

Beberapa contoh risiko yang telah berhasil ditangkap oleh tim pengabdi diantaranya adalah (1) fluktuasi ketersediaan bahan baku limbah kering, (2) frekuensi dan volume penjualan limbah kering yang masih belum stabil, (3) potensi risiko kebakaran. Dari risiko dan potensi risiko yang ada, tim pengabdi memberikan opsi penanganan sebagai berikut, (1) memformulasikan MoU penyesuaian dengan PT. SGM terkait dengan banyaknya jumlah limbah kering yang dapat dipasok ke BUMDes Kemudo Makmur, (2) membuka akses pasar lebih lebar melalui pasar online, melatih lebih banyak penduduk untuk dapat membuat kerajinan palet kayu, (3) penyediaan APAR maupun pemberlakuan aturan dilarang merokok di dalam gudang penyimpanan dikarenakan banyak bahan mudah terbakar. Namun, perlu juga kami sampaikan bahwa dalam pengabdian ini, kami bertujuan lebih untuk meningkatkan kesadaran pengelola BUMDesa Kemudo Makmur akan adanya potensi-potensi risiko 
tersebut, sehingga dalam tindak lanjut upaya mitigasi riil yang telah dilakukan oleh BUMDesa, belum akan kami bahas dalam artikel ini.

\section{SIMPULAN}

Kegiatan Pengabdian Masyarakat ini dapat terselenggara dengan baik dan diharapkan mampu memberikan dampak sesuai dengan diharapkan. Hal ini tercermin dari (1) para pengelola BUMDes dimudahkan dalam membuat laporan keuangan yang terintegrasi secara baik dengan bantuan aplikasi “Akuntansi UKM". Dengan keterbatasan personel yang mahir mengenai akuntansi, aplikasi UKM mampu memberikan jembatan instan bagi para personel BUMDesa yang minim pengetahuan akuntansinya. Hal ini tentu saja penting untuk melaksanakan pertanggungjawaban kinerja BUMDesa kepada para pihak terkait terutama Penasehat maupun Pengawas BUMDesa, (2) para pengelola BUMDes semakin sadar akan pentingnya pemetaan risiko yang berkaitan dengan pengelolaan organisasi yang ada. Hal ini penting dalam rangka menciptakan organisasi yang sadar risiko sehingga dampak apabila risiko itu terjadi dapat diminimalisir. Namun, perlu juga digarisbawahi bahwa perlu ada upaya lebih lanjut untuk melihat dampak Pengabdian Masyarakat ini secara lebih riil pada periode yang akan datang.

\section{DAFTAR PUSTAKA}

BPS Kabupaten Klaten. 2018. Statistik Daerah Kecamatan Prambanan 2018. Klaten: BPS Kab. Klaten.

Susanto, A., \& Meiryani, M. 2018. The Importance of Risk Management in an Organization. International Journal of Scientific \& Technology Research Volume 7, ISSUE 11, 103-107.

Undang-undang no 6 tahun 2014 tentang Desa. (n.d.) 